Jurnal Pilar Teknologi, Volume 3 Nomor 2 Edisi September 2018

ISSN Print : 2502-7042 ISSN Online : 2580-3557

http://pilar.unmermadiun.ac.id

\title{
Nilai Kalor Briket Limbah Kayu Sengon Dengan Perekat Maizena Lebih Tinggi Di Bandingkan Tapioka, Sagu Dan Tepung Singkong
}

\author{
Zainal Arifin ${ }^{1}$, Hantarum ${ }^{2}$, Wahidin Nuriana ${ }^{3}$ \\ ${ }^{1}$ Program Studi Teknik Mesin, Fakultas Teknik Universitas Merdeka Madiun \\ Email : arifian.usa@gmail.com \\ ${ }^{2}$ Program Studi Teknik Mesin, Fakultas Teknik Universitas Merdeka Madiun \\ Email : Hantarum1973@gmail.com \\ ${ }^{3}$ Program Studi Teknik Mesin, Fakultas Teknik Universitas Merdeka Madiun \\ Email : nuriana@unmer-madiun.ac.id
}

\begin{abstract}
Bio-briquette is a solid fuel made from organic waste and mixed with other ingredients and then printed using certain pressures so that the desired shape and characteristics are obtained. This study focused on determining the effect of adhesive on density, moisture content and heating value on sengon wood charcoal bio-briquette with variations of tapioca, sago, cornstarch and cassava flour with a pressure of $115 \mathrm{~kg} / \mathrm{cm}^{2}$. The results showed that the highest density was $0.56 \mathrm{~g} / \mathrm{cm}^{3}$ in the bio-briquette of sengon wood waste charcoal with cassava flour adhesive, the lowest water content was $6.52 \%$ in the bio-briquette of sengon wood waste with cornstarch adhesive and the highest heating value was found in briquettes maizena adhesive sengon wood waste is 5,868 cal / gr.
\end{abstract}

Keywords: sengon wood waste briquettes, adhesive, density, moisture content and heating value

\section{PENDAHULUAN}

Kayu Sengon merupakan jenis tumbuhan yang banyak dijumpai di Indonesia dan dibudidayakan oleh petani untuk dijadikan bahan baku dalam berbagai macam produk yang beragam, mulai dari bahan bangunan, kerajinan, dan bahan penunjang pekerjaan konstruksi . Industri pengolahan kayu sengon banyak di temukan di wilayak pulau jawa. Kayu sengon di pulau jawa umumnya berasal dari hutan rakyat. Data suplai kayu domestik Indonesia sebesar 42,3 juta $m^{3}$ dimana hutan rakyat menyumbang 10 juta $m^{\mathrm{a}}$ (Kemenhut, 2010). Kayu sengon merupakan bahan baku dalam industri pengolahan kayu lapis yang limbah pengolahanya belum tertangani secara maksimal. Hal ini didasari pada studi awal yang menemukan bahwa limbah pengolahan kayu sengon di setiap industri belum terolah secara maksimal oleh pemilik industri, biasanya hanya dibuang begitu saja atau dibakar untuk menghilangkan limbah tersebut sehingga perlu dipikirkan mengenai pengolahan limbah hasil proses produksi dapat dimanfaatkan secara maksimal.

Proses pembriketan merupakan salah satu alternatif pengolahan limbah kayu sengon yang dipandang cukup prospektif untuk dikembangkan sebagai bahan bakar padat. Beberapa keuntungan pembriketan yang menjadikannya sebagai salah satu pengolahan limbah yang cukup prospektif antara lain mampu meningkatkan nilai kalor, densitas, mudah dalam pengemasan dan distribusi, mempunyai kualitas dan ukuran yang beragam serta mudah dalam pembuatan. Pembriketan adalah pembentukan biomassa menjadi briket dengan cara di kompaksi dengan bertujuan untuk meningkatkan sifat bahan baku dan mampu lebih praktis dalam dimensi. Bahan bakar padat ini merupakan bahan bakar alternatif atau merupakan pengganti bahan bakar minyak yang paling murah dan dimungkinkan untuk dikembangkan secara masal dalam waktu yang relatif singkat mengingat teknologi dan peralatan yang digunakan relatif sederhana. 
Beberapa peneliti telah melakukan berbagai macam penelitian pembuatan briket dengan bahan baku biomassa (Husain dkk, 2002; Rhen dkk,2005; Mani dkk, 2006; Saputro dkk, 2007) mereka menyimpulkan bahwa konversi biomassa menjadi briket mampu menaikkan gross calorific value, mampu menaikkan sifat fisik bahan baku (densitas, nilai kalor, kadar air), semakin tinggi tekanan kompaksi mampu menaikkan densitas, compression strength, durability dan stability. Nilai kalor merupakan parameter penting dalam menetukan kualitas briket apabila digunakan sebagai bahan bakar. Besarnya tekanan kompaksi tidak berpengaruh terhadap kandungan energi per satuan massa, nilai kalor bahan bakar dipengaruhi oleh seberapa besar kandungan kadar karbon terikat yang terdapat dalam bahan baku. Hubungan antara densitas dengan nilai kalor menunjukkan kandungan energi per volume, kandungan energi per volume naik seiring dengan naiknya densitas briket. Densitas menjadi parameter penting dalam pembuatan briket, densitas yang tinggi menunjukkan rasio energi per volume yang tinggi (Demirbas, 1999). Hal ini menunjukkan bahwa semakin tinggi densitas dapat meningkatkan energi yang terkandung dalam bahan bakar pada massa yang sama.

Perekat yang sering digunakan pada pembuatan briket antara lain kanji, sagu, tanah liat, semen, natrium silikat dan tetes tebu. Beberapa penelitian sebelumnya yang dilakukan oleh (Setiyono, 2000), membandingkan antara perekat kanji dengan perekat tetes tebu dan dihasilkan briket yang optimal yaitu briket yang menggunakan bahan perekat kanji karena memiliki kuat tekan dan nilai kalor yang lebih tinggi. Penelitian lain dilakukan oleh Lestari dkk, (2010), yang membandingkan antara perekat sagu dan perekat kanji. Dari hasil penelitian tersebut juga dihasilkan perekat yang lebih baik yaitu perekat kanji karena memiliki kandungan air dan abu yang rendah dan karbon yang lebih tinggi dibandingkan dengan perekat sagu. Tepung kanji di timbang sebanyak $10 \%$ dari berat bahan baku per satuan briket. Angka 10 persen ini masih termasuk ambang batas ketentuan bahan pengikat sesuai pedoman permen ESDM No. 047 Tahun 2006 sebesar 5\%-10\%. Tepung kanji dan air dimasak sebagai lem, dengan perbandingan $60 \mathrm{~g}$ tepung kanji dicampur dengan air $200 \mathrm{~mL}$ dimasak hingga mendidih dalam jumlah $10 \%$ bobot terhadap total briket (Nuriana dkk, 2013).

\section{METODE PENELITIAN}

Bahan :

Limbah kayu sengon,Tepung tapioka, Tepung Sagu, Tepung Maizena, Tepung Singkong dan Air.

Peralatan :

Oven, Blender, Baskom, Ayakan, Stopwatch, Timbangan digital dan Neraca Ohaus, Alat pres hidrolik dengan alat ukur tekanan, Cetakan briket berdiameter 4,9 mm, Jangka sorong, Bomb Kalorimeter.

Pembuatan spesimen :

Limbah kayu sengon di potong kecil sekitar $10 \mathrm{~cm}$ kemudian masuk proses karbonasi selama \pm 60 menit pada suhu $400{ }^{\circ} \mathrm{C}$. Arang hasil karbonisasi ditumbuk kemudian di blender hingga halus dan di ayak dengan dengan ukuran 60 mesh, 80 mesh. Perekat dibuat dari tepung tapioka yang dilarutkan oleh air dengan perbandingan $75 \%$ dan $25 \%$. Mencampurkan arang kayu sengon dan perekat dengan perbandingan $70 \%$ dan 30\%.Campuran dimasukan pada cetakan dan dipadatkan menggunakan alat pres hidrolik dengan tekanan $115 \mathrm{~kg} / \mathrm{cm}^{2}$ ditahan selama 2 menit. Kemudian briket dikeluarkan dari cetakan dan dikeringkan ditemperatur $100^{\circ} \mathrm{C}$ selama 60 menit, briket arang siap diuji.

Penentuan Densitas :

Perhitungan nilai densitas dilakukan berdasarkan ASTM B-311-93 nilai densitas dapat diperoleh dengan rumus sebagai berikut :

$$
\begin{aligned}
& \rho=\frac{m}{v} \\
& \text { Keterangan : } \\
& \rho=\text { Massa jenis }\left(\mathrm{g} / \mathrm{cm}^{3}\right) \\
& m=\text { Massa briket }(\mathrm{g}) \\
& v=\text { Volume }\left(\mathrm{cm}^{3}\right)
\end{aligned}
$$

Penentuan Kadar Air :

Penentuan kadar air dilakukan dengan pengovenan biobriket dalam oven $105^{\circ}$ selama 60 menit kemudian didinginkan dalam desikator dan diulang 2 kali agar didapatkan berat yang konstan.

Besarnya kadar air dapat dihitung menggunakan standar ASTM D 5142 dengan persamaan sebagai berikut : Kadar Air $=\frac{X_{1}-X_{2}}{X_{1}} \times 100 \%$

Keterangan :

$$
\begin{aligned}
& X_{1}=\text { berat sampel mula-mula }(\mathrm{gram}) \\
& X_{2}=\text { berat sampel setelah di oven }(\mathrm{gram})
\end{aligned}
$$

Nilai Kalor :

Standar pengujian yang digunakan adalah standar ASTM untuk sampel batubara, dengan alasan bahwa briket arang limbah kayu sengon adalah bahan bakar padat, sama seperti batubara.

Perhitungan nilai kalor :

Nilai kalor contoh briket dapat dihitung dengan persamaan sebagai berikut :

$$
\text { Nilai kalor HHV }(\mathrm{cal} / \mathrm{g})=\frac{[(\Delta t) x E E V]-\left(e_{1}+e_{2}\right)}{m}-e_{g}
$$

Dimana :

$\Delta \mathrm{t}$ adalah kenaikan suhu pembakaran di dalam bomb kalorimeter $\left({ }^{\circ} \mathrm{C}\right)$

$E E V$ adalah energi ekivalen saat terjadi pembakaran $\left(\mathrm{cal} /{ }^{\circ} \mathrm{C}\right)$

$e_{1}$ adalah koreksi panas karena pembentukan asam (cal)

$e_{2}$ adalah koreksi panas pembakaran dari kawat pembakaran (cal)

$\otimes_{g}$ adalah koreksi sulfur yang ada dalam bahan bakar (cal/g)

$m$ adalah briket contoh $(\mathrm{g})$

\section{HASIL DAN PEMBAHASAN}

Tabel 1. Hasil data Rekap pengujian pengaruh perekat pada briket limbah kayu sengon. 


\begin{tabular}{ccccc}
\hline No & $\begin{array}{c}\text { Bahan } \\
\text { Perekat }\end{array}$ & $\begin{array}{c}\text { Uji } \\
\text { Densitas } \\
\left(\mathbf{k g} / \mathbf{c m}^{\mathbf{3}}\right)\end{array}$ & $\begin{array}{c}\text { Uji Kadar } \\
\text { Air } \\
(\%)\end{array}$ & $\begin{array}{c}\text { Uji Nilai } \\
\text { Kalor } \\
(\mathbf{k a l} / \mathbf{g})\end{array}$ \\
\hline 1 & Tapioka & 0,53 & 8,74 & 5,700 \\
2 & Sagu & 0,53 & 10,78 & 5,779 \\
3 & Maizena & 0,49 & 6,52 & 5,898 \\
4 & $\begin{array}{c}\mathrm{T} \\
\end{array}$ & 0,56 & 9,37 & 5,770 \\
\hline
\end{tabular}

Nilai densitas tertinggi sebesar $0,56 \mathrm{~g} / \mathrm{cm}^{\mathrm{a}}$ pada komposisi perekat tepung singkong, sedangkan nilai densitas terendah $0,49 \mathrm{~g} / \mathrm{cm}^{\mathrm{a}}$ pada komposisi tepung maizena. Nilai densitas yang diperoleh dari pengujian nilai densitas hanya mempunyai selisih yang sedikit karena perlakuan yang diberikan pada semua komposisi briket pada saat pengayakan sama yaitu sebesar 60 mesh dan tekanan yang diberikan pada saat percetakan sebesar $115 \mathrm{~kg} / \mathrm{cm}^{2}$, adapun perbedaan yang di hasilkan briket terdapat retakan di setiap sisi disebabkan karena massa arang atau bahan limbah kayu sengon terlalu ringan di banding dengan kayu lain yang memiliki massa lebih tinggi dari pada kayu sengon.

Kadar air

Pengujian kadar air dilakukan dengan menimbang

Berdasarkan hasil rekap data pengujian pengaruh perekat tapioka, sagu, maizena dan tepung singkong terhadap nilai densitas, kadar air dan nilai kalor dapat di lihat pada tabel 4.4 dengan hasil uji densitas yaitu $\left(0,53 \mathrm{~kg} / \mathrm{cm}^{3}\right),(0,53$ $\left.\mathrm{kg} / \mathrm{cm}^{3}\right),\left(0,49 \mathrm{~kg} / \mathrm{cm}^{3}\right),\left(0,59 \mathrm{~kg} / \mathrm{cm}^{3}\right)$. Hasil uji kadar air yaitu $(8,74 \%),(10,78 \%),(6,52 \%),(9,37 \%)$. Dan hasil uji nilai kalor yaitu $(5,700 \mathrm{kal} / \mathrm{g}),(5,779 \mathrm{kal} / \mathrm{g}),(5,868 \mathrm{kal} / \mathrm{g}),(5,770$ $\mathrm{kal} / \mathrm{g}$ ).

\section{Kerapatan}

Kerapatan menunjukkan perbandingan antara massa dan volume briket. Kerapatan briket berpengaruh terhadap kualitas briket, karena kerapatan yang tinggi dapat meningkatkan kualiatas briket. Besar atau kecilnya kerapatan tersebut dipengaruhi oleh kehomogenan bahan perekat penyusun briket itu sendiri.

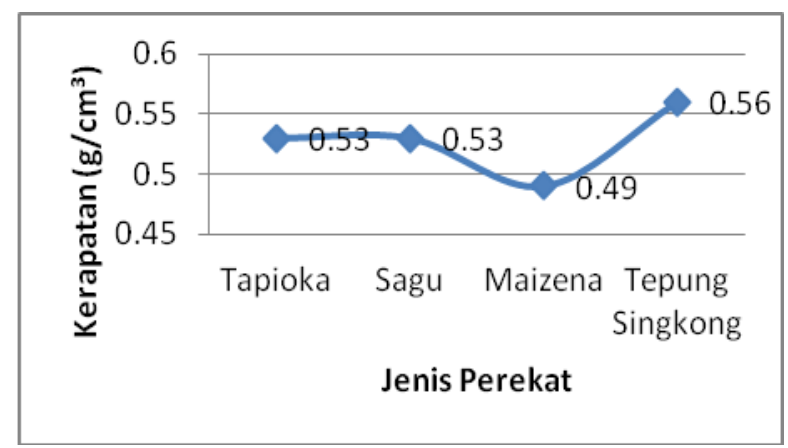

Gambar 1. Grafik pengaruh perekat tapioka, sagu, maizena dan tepung singkong terhadap densitas briket limbah kayu sengon.

Berdasarkan grafik di atas nilai densitas briket paling tinggi, yaitu pada jenis perekat tepung singkong dengan nilai densitas $0,56 \mathrm{~g} / \mathrm{cm}^{\mathrm{a}}$. Semakin meningkat konsentrasi perekat akan semakin meningkat nilai densitas briket. Hal ini terjadi karena daya rekat pada tapioka dengan konsentrasi tinggi akan lebih tinggi daya rekatnya (Nugrahaeni, 2007).

Densitas menunjukan perbandingan antara berat dan volume briket arang limbah kayu sengon. Besar kecilnya densitas dipengaruhi oleh ukuran dan kehomogenan arang penyusun briket arang tersebut. Nilai densitas briket pengaruh variasi perekat dapat ditunjukan pada grafik 1 . briket untuk mengetahui massa briket kayu sengon sebelum di oven $110^{\circ} \mathrm{C}$ selama 60 menit. Briket kayu sengon di dinginkan di desikator selama beberapa menit hingga briket menjadi dingin. Menimbang massa briket kayu sengon setelah dingin, briket kayu sengon di oven, di dinginkan, dan ditimbang lagi hingga mencapai berat konstan. Menghitung kadar air pada briket, menghitung selisih massa awal briket dengan massa briket konstan, lalu dibagi dengan massa awal setelah itu dikalikan $100 \%$.

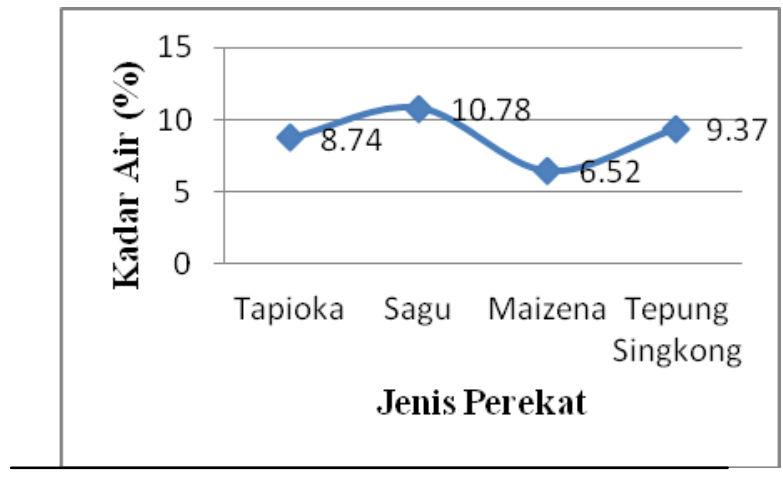

Gambar 2. Grafik pengaruh perekat tapioka, sagu, maizena, dan tepung singkong terhadap kadar air pada briket limbah kayu sengon.

Berdasarkan grafik diatas dengan komposisi perekat yang sama yaitu 6 gram didapatkan hasil kadar air untuk masing-masing briket dengan jenis perekat tepung tapioka, tepung sagu, tepung maizena, dan tepung singkong yaitu $8,74 \%, 10,78 \%, 6,52 \%$, dan $9,37 \%$. Berdasarkan data yang dihasilkan nilai kadar air terendah terdapat pada jenis perekat tepung maizena dan nilai tertinggi pada jenis perekat tepung sagu, jadi dapat diketahui nilai kadar air terendah terdapat pada briket yang komposisinya tepung maizena karean sukar mengikat air, sedangakan nilai kadar air tertinggi pada briket dengan komposisi perekat tepung sagu karena cederungu banyak mengikat air. sedangakan nilai kadar air tertinggi pada briket dengan komposisi perekat tepung sagu karena cederungu banyak mengikat air. Hal ini dikarnakan kandungan air yang terdapat dalam perekat sehingga dicampur dengan arang limbah kayu sengon akan berpengaruh terhadap nilai kadar air briket tersebut (Purnama, dkk 2012).

Penelitian dilakukan Gandhi (2010), menyatakan, adanya penambahan perekat yang banyak otomatis 
meningkatkan nilai kadar air yang banyak sebagai media pelarut tepungnya. Perlakuan kadar perekat memberikan pengaruh yang nyata terhadap kadar air briket, sehingga dengan kadar perekat yang semakin tinggi maka kadar air briket yang dihasilkan semakin tinggi juga. Hubungan ini dapat disebabkan karena air yang terkandung dalam perekat akan masuk dan terikat dalam pori arang (Saktiawan, 2000). Penambahan air dalam setiap persentase perekat yang semakin meningkat menyebabkan jumlah air yang dapat diikat dalam pori arang semakin banyak sehingga memberikan penambahan terhadap kadar air briket arang.

Menurut Wijayanti 2009, kadar air yang tinggi diduga jumlah pori-pori masih cukup banyak dan mampu menyerap air, sesuai dengan penelitian Triono 2006, dimana jumlah pori-pori yang lebih banyak dan adanya kandungan komponen-komponen kimia, seperti selulosa, lignin, dan hemiselulosa juga dapat mempengaruhi adanya kandungan nilai kadar air yang tinggi pada briket.

\section{Nilai Kalor}

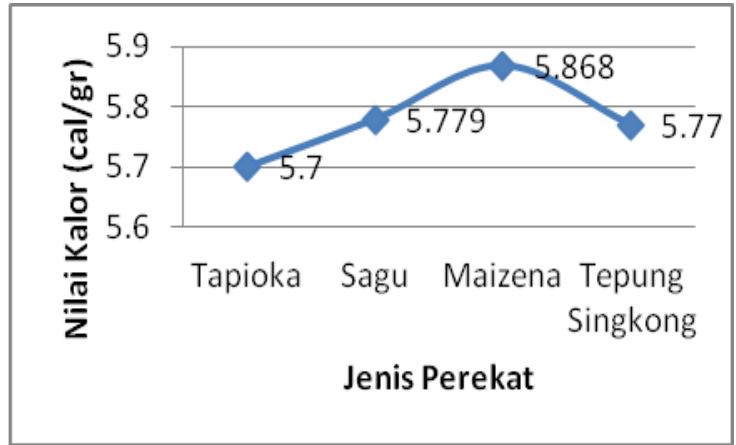

Gambar 3. Grafik pengaruh perekat tapioka, sagu, maizena dan tepung singkong terhadap nilai kalor pada briket limbah kayu sengon.

Berdasarkan grafik diatas dengan komposisi perekat yang sama yaitu 6 gram didapatkan hasil nilai kalor untuk masing-masing briket dengan jenis perekat tepung tapioka, tepung sagu, tepung maizena dan tepung singkong yaitu 5,700 $\mathrm{cal} / \mathrm{gr}, 5,779 \mathrm{cal} . \mathrm{gr}, 5,868 \mathrm{cal} / \mathrm{gr}$ dan 5,770 cal/gr. Berdasarkan data yang dihasilkan nilai kalor tertinggi terdapat pada jenis perekat tepung maizena yaitu $5,868 \mathrm{cal} / \mathrm{gr}$ dan terendah pada jenis tepung tapioka yaitu $5,700 \mathrm{cal} / \mathrm{gr}$. Sehingga pada grafik terlihat bahwa untuk setiap perekat briket akan mempunyai nilai kalor tinggi apabila kadar air semakin rendah sebaliknya nilai kalor rendah dipengaruhi kadar air yang tinggi. Hal ini dikarnakan tepung maizena tidak terlalu banyak mengikat air mengakibatkan air didalam pori-pori mudah menguap, sedangkan perekat tepung tapioka, tepung sagu dan tepung singkong memiliki daya rekat yang kuat mengakibatkan kandungan air yang berada didalam terikat dalam pori-pori sehingga tak mudah keluar saat pengeringan terjadi.

Menurut Triono (2006), grafik diatas dikatakan bahwa semakin rendah kadar air dan kadar abu briket, maka akan meningkatkan nilai kalor briket. Selain itu juga nilai kalor dipengaruhi oleh kadar karbon terikat yang terkandung di dalam briket yang dihasilkan.

\section{KESIMPULAN}

Kesimpulan yang dapat diperoleh dari penelitian ini adalah sebagai berikut :

1. Pengaruh perekat terhadap densitas briket limbah kayu sengon yaitu pada jenis perekat tepung tapioka sebesar $0,53 \mathrm{~g} / \mathrm{cm}^{\mathrm{a}}$, tepung sagu $0,53 \mathrm{~g} / \mathrm{cm}^{\mathrm{a}}$, tepung maizena $0,49 \mathrm{~g} / \mathrm{cm}^{\mathrm{a}}$, dan tepung singkong $0,56 \mathrm{~g} / \mathrm{cm}^{\mathrm{a}}$.

2. Pengaruh perekat terhadap kadar air limbah kayu sengon yaitu pada jenis tepung tapioka sebesar $8,74 \%$, tepung sagu sebesar $10,78 \%$, tepung maizena sebesar $6,52 \%$, dan tepung singkong sebesar $9,37 \%$.

3. Pengaruh perekat terhadap nilai kalor yang dihasilkan dari setiap konsentrasi masing-masing perekat yaitu pada jenis tepung tapioka sebesar $5,700 \mathrm{cal} / \mathrm{gr}$, tepung sagu sebesar 5,779 cal/gr,

\section{DAFTAR PUSTAKA}

Gandhi, A. 2010. Pengaruh Variasi Jumlah Campuran Perekat. Jurnal Profesional Vol.8. no.1.hal.1.12. Semarang: SMKN 7 Semarang.

Husain Z., Zainal Z., Abdullah,. 2002. Curing temperature effect on mechanical strength of smokeless fuel briquettes prepared with molasses, Biomass and Bioenergy 22, PP. 505-509.

[Kemenhut] Kemenhut. 2010. Nomor : P.08/Menhut-li/2010 Tentang Rencana Strategi (Renstra) Kementeria Kehutanan Tahun 2010-2014. Jakarta.

Lestari L, Aripin, Yanti, Zainuddin, Sukmawati, Marliani. 2010. Analisa Kualitas Briket Arang Tongkol Jagung yang Menggunakan Bahan Perekat Sagu dan Kanji. Jurnal aplikasi fisika Vol. 6, No. 2 Agustus 2010. Kendari: Jurusan Fisika FMIPA Universitas Haluoleo

Mani S, Lope G., Sokhansany S., 2004, Grinding Performance an physical properties of weat and barley straws, corn stover and switchgrass, Biomass \& Bioenergy, Vol. 27, pp. 339-352

Nugrahaeni YI.2007. Pemanfaatan Limbah Tembakau (Nicotiana Tabacum L) untuk Bahan Pembuatan Briket sebagai Bahan Bakar Alternatif [Skripsi] Bogor: Institut Pertanian Bogor.

Nuriana, W., Anisa. N, Martana. 2013. Karakteristik Biobriket Kulit Durian Sebagai Bahan Bakar Alternatif Terbarukan. Jurnal Teknologi Ilmu Pertanian 23 (1):70-76.

Rhen C., Gref R. Sjostrom M., Wasterlud I., 2005, Effect raw material, moisture content, densification pressure and temperature on some properties of Norway spruce pellets, Fuel Processing Technology, vol. 87, pp. 11-16

Purnama, R.R., A. Chumaidi, and A. Saleh. 2012. Pemanfaatan Limbah Cair CPO Sebagai Perekat Pada Pembuatan Briket dari Arang Tandan Kosong Kelapa Sawit. 18:45.

Saputro D.D., Widayat W., 2007-a, Biomassa sebagai sumber energi alternatif terbarukan di Indonesia, Jurnal Profesional, Vol 5, No.2, pp. 705-716

Setiyono, 2002. Pembuatan Briket Arang dari Tempurung Kelapa dengan Bahan Pengikat Tetes Tebu 
dan Tapioka. Jurnal Kimia dan Teknologi. Surabaya: Jurusan Teknik Kimia FakultasTeknologi Industri-UPN Veteran.

Saktiawan , I. 2000. Identifikasi Sifar Fisik dan Kimia Briket Arang Dari Sabut Kelapa (Cocos nucifera L,). Skripsi. Jurusan Teknologi Hasil Hutan, IPB. (Tidak dipublikasikan).

Triono, A. 2006. Karakteristik Briket Arang dari Campuran Serbuk Kayu Afrika (maesopsis Emini;Engl) dan Sengon (Paraserianthes Falcatariala) dengan PenambahanTempurung Kelapa (Cacos nuciferal) [Skripsi]. Bogor. Departemen Hasil Hutan. Fakultas Pertanian. Institut Pertanian Bogor.

Wijayanti, D.S. 2009. Karakteristik Briket Arang dari Serbuk Gergaji dengan Penambahan Arang Cangkang Kelapa Sawit. Jurnal Teknik Pertanian. 